\author{
Н. В. Зайцева, И. Н. Кандричина \\ Белорусский национальный технический университет
}

\title{
СОЦИАЛЬНОЕ ПАРТНЕРСТВО: ИСТОРИЯ И СОВРЕМЕННОСТЬ
}

\begin{abstract}
Статья посвящена анализу развития и становления системы социального партнерства. Социальное партнерство представляет собой особую систему отношений, возникающих между наемными работниками и работодателями при посреднической роли государства, по согласованию экономических интересов в социально-трудовой сфере и урегулированию социально-трудовых конфликтов. Это также эффективная форма организации и осуществления социально-экономической политики государства на основе учета интересов различных слоев и групп общества путем ведения переговоров. В современном мире сегодня социальное партнерство - это основная и необходимая составляющая трудовых отношений. Оно способствует устойчивому и гармоничному развитию общества.
\end{abstract}

Ключевые слова: социально-трудовые отношения, наемные работники, наниматель, рабочая сила, профсоюзное движение, коллективный договор.

Для цитирования: Зайцева Н. В., Кандричина И. Н. Социальное партнерство: история и современность // Труды БГТУ. Сер. 6, История, философия. 2021. № 2 (251). С. 74-76.

\author{
N. V. Zaytseva, I. N. Kandrichina \\ Belarusian National Technical University
}

\section{SOCIAL PARTNERSHIP: HISTORY AND MODERNITY}

The article is devoted to the analysis of the development and development of the social partnership system. The social partnership is a special system of relations arising between employees and employers with the mediation role of the state, in coordinating economic interests in the socially labor sphere and the settlement of socio-labor conflicts. It is also an effective form of the organization and development of the socio-economic policy of the state based on accounting for the interests of various layers and groups of society by negotiating. In the modern world of this day, the social partnership is the basic and necessary component of labor from nothing. It contributes to the sustainable and harmonious development of society.

Keywords: social and labor relations, employees, employer, labor force, trade union movement, collective agreement.

For citation: Zaytseva N. V., Kandrichina I. N. Social partnership: history and modernity. Proceeding of BSTU, issue 6, History, Philosophy, 2021, no. 2 (251), pp. 74-76 (In Russian).

Введение. Социальное партнерство - это система отношений межу наемными работниками и нанимателем при посредничестве государства. Эти отношения призваны регулировать экономические интересы с учетом социальных. Развитие системы социального партнерства - важнейший аспект современных социально-экономических отношений.

Основная часть. Система социального партнерства как одна из основных форм регулирования социально-трудовых отношений зародилась в середине XX в., после окончания Второй мировой войны как отражение нового мироустройства и миропорядка. Однако официальную форму она приняла лишь в 1960-1970 гг. Сама же необходимость регулирования социально-трудовых отношений возникает одновременно с появлением капиталистического товарного производства, когда в качестве основных субъектов трудовых отношений окончательно оформляются два основных класса - собственники средств производства и наемные работники, лишенные средств производства и потому вынужденные продавать свою рабочую силу, чтобы как-то обеспечить свое существование.

Но если рассматривать социальное партнерство с исторического аспекта, то его становление и развитие неразрывно связано с возникновением и развитием профсоюзного движения.

В Беларуси профессиональные союзы стали создаваться раньше, чем в центральных губерниях Российской империи - еще в середине 90-х гг. ХIX в. Но наиболее значимую форму они приобрели после событий 1905 г. Всего к концу мая 1907 г. на территории Северо-Западного края существовал 101 профсоюз, в них насчитывалось 14553 члена. Тем самым была создана организационная основа для трехсторонних отношений в социально-трудовой сфере: работодатели - наемные работники - государство. 
Зарождению социального партнерства способствовали также развитие кооперативного движения, организация акционерных товариществ, создание земских учреждений. После событий 1905-1907 гг. профсоюзное движение подверглось репрессиям со стороны правящих властей. И к 1910 г. легальные профсоюзы в Гродненской, Минской и Могилевской губерниях были полностью разгромлены, сохранились лишь 5 легальных профсоюзов в Витебске. Их деятельность продолжалась в подполье [1].

Если рассматривать историю развития социального партнерства в неразрывной связи с профсоюзным движением, то дальнейшим этапом будет 1917 г. К этому времени не осталось ни одной профессии, где не были бы созданы свои профсоюзные организации [2].

Однако истоки социального партнерства находятся более глубоко - в сфере взаимодействия интересов труда и капитала. И следствием такого взаимодействия является нивелирование социальных конфликтов. Правящий класс должен был не только определять сферу договорных отношений, но и нести ответственность за ее содержание. Государство и правящий класс определяли правовой статус как индивидуальных, так и коллективных субъектов, а также правовые средства разрешения трудовых конфликтов.

Социальное партнерство представляет собой особую систему отношений, возникающих между наемными работниками и работодателями при посреднической роли государства, по согласованию экономических интересов в социальнотрудовой сфере и урегулированию социальнотрудовых конфликтов. Систему социального партнерства называют «трипартизмом», так как в регулировании социально-трудовых отношений участвуют три стороны: организации, представляющие интересы наемных работников, объединения работодателей и государство.

Наиболее эффективные механизмы социального партнерства на сегодняшний день характерны для развитых европейских государств, таких как Германия, Франция, Австрия, Швеция и др. [3].

На постсоветском пространстве становление и развитие социального партнерства имеет свои особенности. Здесь можно выделить несколько периодов его развития:

1917-1921 гг. - период отмены прежней правовой базы трудовых отношений и становление новой;

1922-1929 гг. - период НЭП, процесс возрождения коллективных отношений в социально-трудовой сфере;

1930-1946 гг. - период главенства принципа единоначалия на производстве и во всех сферах жизнедеятельности общества;
1947-1964 гг. - период возобновления заключения коллективных договоров, а после 1954 г. т. н. «оттепель» затронула не только политическую сферу, но и социально-экономическую;

1964-1984 гг. - период создание системы коллективно-договорных отношений на производственном, отраслевом, территориальном, республиканском и общесоюзном уровнях. И одновременно это этап утверждение корпоративно-номенклатурного подхода в решении актуальных проблем социально-трудовой сферы;

1985-1991 гг. - кризис советской системы социально-трудовых отношений; развитие новых форм организации и стимулирования труда; введение хозрасчета, самофинансирования, самоуправления на производстве; развитие рабочего движения; возникновение новых независимых профсоюзов, формирование новых подходов в практике заключения коллективных договоров и соглашений [4].

В настоящее время социальное партнерство основывается на принципах, обозначенных Международной организацией труда (МОТ), законодательных и нормативно-правовых актах стран мирового сообщества.

Международная организация труда в 1919 г. Лигой Наций (предшественник $\mathrm{OOH}$ ) была создана на основе трипартизма. Ее главной функцией является установление правопорядка между наемными работниками, работодателями и государством, т. е. основная цель МОТ - установление социальной справедливости и мира. Характерной чертой МОТ является участие представителей предпринимателей, правительства и организаций, трудящихся в ее составе. Со времен основания МОТ приняла 190 конвенций и более 200 рекомендаций по социальнотрудовым вопросам [5].

Заключение. Республика Беларусь является членом МОТ с 1954 г. и ратифицировала 51 ее конвенцию, в том числе 8 основополагающих. Членство в МОТ позволяет Беларуси изучать и применять международную практику урегулирования социально-трудовых споров, развивать социальное партнерство (правительство - профсоюзы - предприниматели), совершенствовать и регулировать рынок труда [5]. Участие в деятельности МОТ помогает разрабатывать основанные на мировом опыте нормы трудового законодательства, содействует развитию предпринимательства, решению проблем занятости.

Республика Беларусь придерживается основополагающих принципов социального партнерства. В ст. 352 Трудового Кодекса Республики Беларусь указано, что социальное партнерство - это форма взаимодействия органов государственного управления, объединений нанимателей, профессиональных союзов и иных представительных 
органов работников, уполномоченных в соответствии с актами законодательства представлять их интересы, (субъектов социального партнерства) при разработке и реализации социально-экономической политики государства, основанная на учете интересов различных слоев и групп общества в социально-трудовой сфере посредством переговоров, консультаций, отказа от конфронтации и социальных конфликтов. По состоянию на
1 января 2021 г. в отраслях экономики республики заключено 17,1 тыс. коллективных договоров (в том числе в 2020 г. заключены впервые 399 коллективных договоров), действие которых распространяется на 18,5 тыс. организаций [6].

Сегодня в современном мире социальное партнерство - это неотъемлемая часть трудовых отношений.

\section{Список литературы}

1. Дубовик А. К. Исторический опыт становления социального партнерства в Беларуси // Официальный сайт исторического факультета БГУ. URL: https:/hist.bsu.by/images/stories/files/nauka/ izdania/tif/2/Dubovik.pdf (дата обращения: 08.09.2021).

2. Очерки истории профсоюзов Белоруссии. 1905-1969 гг. Минск: Изд-во БГУ, 1970. С. 31.

3. Генг В. А., Андреева А. В. Мировая практика социального партнерства в трудовой сфере: история становления // Вестник ТвГУ. URL: https://core.ac.uk/download/pdf/74272246.pdf (дата обращения: 08.09.2021).

4. Делегеоз Е. Г. Социальное партнерство в России: исторические основы становления и развития // Научная электронная библиотека «КиберЛенинка». URL: https://cyberleninka.ru (дата обращения: 08.09.2021).

5. Международная организация труда // Сайт Министерства иностранных дел. URL: https://mfa.gov.by/mulateral/organization/list/e241440429443799.html (дата обращения: 08.09.2021).

6. Социальное партнерство // Сайт Федерации профсоюзов Беларуси. URL: https://fpb.1prof.by/ socialnoe-partnerstvo/ (дата обращения: 08.09.2021).

\section{References}

1. Dubovik A. K. Istoricheskiy opyt stanovleniya sotsial'nogo partnerstva v Belarusi [Historical experience of formation of social partnership in Belarus]. Available at: https://hist.bsu.by/images/ stories/files/nauka/izdania/tif/2/Dubovik.pdf (accessed 08.09.2021).

2. Ocherki istorii profsoyuzov Belorussii. 1905-1969 gg. [Essays of the history of trade unions of Belarus. 1905-1969]. Minsk, Izd-vo BGU Publ., 1970. P. 31.

3. Geng V. A., Andreeva A. V. Mirovaya praktika sotsialnogo partnerstva v trudovoy sfere: istoriya stanovleniya [World practice of social partnership in the labor sphere: the history of formation]. Available at: https://core.ac.uk/download/pdf/74272246.pdf (accessed 08.09.2021).

4. Delegeoz E. G. Sotsialnoye partnerstvo v Rossii: istoricheskiye osnovy stanovleniya i razvitiya [Social partnership in Russia: the historical foundations of formation and development]. Available at: https://works.doklad.ru/view/3WgxExKjXDQ.htm (accessed 08.09.2021).

5. Mezhdunarodnaya organizatsiya truda [The International Labour Organization]. Available at: https://mfa.gov.by/mulateral/organization/list/e241440429443799.html (accessed 08.09.2021).

6. Sotsialnoye partnerstvo [Social partnership]. Available at: https://fpb.1prof.by/socialnoe-partnerstvo/ (accessed 08.09.2021).

\section{Информация об авторах}

Зайцева Надежда Викторовна - кандидат исторических наук, доцент, доцент кафедры «Экономика и право». Белорусский национальный технический университет (220013, Минск, пр-т Независимости, 65, Республика Беларусь). E-mail: nadezhda_zaytseva_1972@ mail.ru.

Кандричина Ирина Николаевна - кандидат социологических наук, доцент, доцент кафедры «Менеджмент». Белорусский национальный технический университет (220013, Минск, пр-т Независимости, 65, Республика Беларусь).

\section{Information about the authors}

Zaytseva Nadezhda Viktorovna - PhD (History), Associate Professor, Assistant Professor, the Department of Economics and Law. Belarusian National Technical University (65, Nezavisimosti Ave., 220013, Minsk, Republic of Belarus).E-mail: nadezhda_zaytseva_1972@ mail.ru.

Kandrichina Irina Nikolaevna $-\mathrm{Ph} \overline{\mathrm{D}}$ (Sociology), Associate Professor, Assistant Professor, the Department of Management. Belarusian National Technical University (65, Nezavisimosti Ave., 220013, Minsk, Republic of Belarus). 